\title{
Effects of grafting combinations on the nutritional composition of pepper fruit
}

\author{
Paloma Sánchez-Torres ${ }^{1}$, María Dolores Raigón ${ }^{2}$, Najet Gammoudi ${ }^{3}$ and Carmina Gisbert ${ }^{4, \star}$ \\ 1 Centro de Protección Vegetal y Biotecnología, Instituto Valenciano de Investigaciones Agrarias (IVIA), Apartado Oficial, 46113-Moncada, \\ Valencia, Spain \\ 2 Departamento de Química, Escuela Técnica Superior de Ingeniería Agronómica y del Medio Natural, Universidad Politécnica de Valencia \\ Camino de Vera s/n 46022 Valencia, Spain \\ 3 Arid and Oases Cropping Laboratory, Arid Lands Institute (IRA), Medenine 4119, Tunisia \\ 4 Instituto de Conservación y Mejora de la Agrodiversidad Valenciana (COMAV), Universidad Politécnica de Valencia Camino de Vera s/n \\ 46022 Valencia, Spain
}

Received 12 January 2016 - Accepted 3 April 2016

\begin{abstract}
Introduction. Interest in grafting onto rootstocks resistant to soil-borne pathogens has risen since the phasing-out of methyl bromide, an efficient soil disinfectant. In this study, we have evaluated the putative effect of rootstock-scion combinations on pepper fruit nutritional quality in relation to grafting, an effect that is sometimes overlooked. Materials and methods. As the scions, we used two representative sweet pepper cultivars, 'Almuden' and 'Coyote', and as rootstocks 'Foc' and 'Charlot', both resistant to Phytophthora capsici and Meloidogyne incognita. Dry matter, soluble solids, proteins, phenolics, and vitamin $\mathrm{C}$ content, as well as eight minerals $(\mathrm{P}, \mathrm{K}, \mathrm{Ca}, \mathrm{Mg}, \mathrm{Na}$, $\mathrm{Fe}, \mathrm{Cu}$, and $\mathrm{Zn}$ ) were measured in fruits from non-grafted, self-grafted, and grafted plants. Results and discussion. Differences in the fruit composition were found, depending on the genotype, rootstock, or rootstock-scion combination. The main effects were as follows. Higher values of ${ }^{\circ}$ Brix, phenolics, $\mathrm{P}, \mathrm{Mg}$, and $\mathrm{Na}$ were found in the fruit of 'Coyote' whereas the vitamin $\mathrm{C}$ and Fe levels were higher in 'Almuden' fruit. The dry matter, protein, and $\mathrm{K}$ concentrations were higher in the fruit from grafted plants with respect to the values from non-grafted plants, especially in the fruit from plants grafted onto 'Charlot' and 'Foc' rootstocks (increases of 11.8\%, 17.6\%, and 9.6\%, respectively; when average values of the four combinations of these rootstocks). Fruit from 'Almuden' and 'Coyote' plants grafted onto the rootstock 'Foc' had lower ${ }^{\circ}$ Brix values (about one degree less than the control) and lower values of phenolics were also obtained when used this rootstock ( $14.4 \%$ less than for the control). On the other hand, the P concentration was higher in the fruit of 'Coyote' grafted onto 'Charlot' (17.2\% higher than for the control). This combination also exhibited the highest fruit $\mathrm{K}$ concentration $\left(226.70 \mathrm{mg} 100 \mathrm{~g}^{-1}\right.$ fresh weight). Conclusion. From a nutritional point of view it is important to evaluate and select the best rootstock-scion combinations: in our assay, this was 'Charlot'-'Coyote' the fruit of which showed the highest ${ }^{\circ}$ Brix and K, P, and protein concentrations.
\end{abstract}

Keywords: pepper / Capsicum annuum / fruit quality / mineral composition / rootstockscion combination

Résumé - Effets des combinaisons de greffage sur la composition nutritionnelle des fruits du poivron. Introduction. L'intérêt du greffage sur des porte-greffes résistants aux pathogènes du sol a augmenté depuis l'interdiction du bromure de méthyle, un efficace désinfectant des sols. Dans cette étude, nous avons évalué l'effet putatif de combinaisons porte-greffe-greffon sur la qualité nutritionnelle des fruits de piment qui peut être touchée par greffage et qui est parfois négligée. Matériel et méthodes. Comme greffon, nous avons utilisé deux variétés représentatives de piment doux : 'Almuden' et 'Coyote', et comme porte-greffes : 'Foc' et 'Charlot', résistants à la fois à Phytophthora capsici et à Meloidogyne incognita. La matière sèche, les contenus en solides solubles, protéines, composés phénoliques, vitamine $\mathrm{C}$, ainsi qu'en huit minéraux $(\mathrm{P}, \mathrm{K}, \mathrm{Ca}, \mathrm{Mg}, \mathrm{Na}, \mathrm{Fe}, \mathrm{Cu}$ et $\mathrm{Zn})$ ont été mesurés dans les fruits de plantes non greffées, auto-greffées et greffées. Résultats et discussion. Différentes compositions de fruits ont été trouvées dépendamment de génotype, de porte-greffe et de combinaison porte-greffe-greffon.

\footnotetext{
^ Corresponding author: cgisbert@btc.upv.es
} 


\begin{abstract}
Les principaux effets que nous avons observés sont les suivants : de plus hauts ${ }^{\circ}$ Brix et de plus fortes teneurs en composés phénoliques, $\mathrm{P}, \mathrm{Mg}$ et $\mathrm{Na}$ ont été trouvés dans les fruits 'Coyote', tandis que, les teneurs en vitamine $\mathrm{C}$ et en Fe étaient plus élevées dans les fruits d'Almuden'. La teneur en matière sèche, en protéines et en K étaient plus élevées dans les fruits des plantes greffées, par rapport aux ceux des non greffées, principalement dans le cas des plantes greffées sur 'Charlot' ou sur 'Foc' (augmentation de 11,8\%, 17,6 \% et 9,6\% respectivement, en valeur moyenne de quatre combinaisons de ces porte-greffes). Les fruits d'Almuden' et 'Coyote' à partir des plantes greffées sur le portegreffe 'Foc' avaient un ${ }^{\circ}$ Brix inférieur (environ un degré moins par rapport au contrôle) et des teneurs inférieures en composés phénoliques ont également été obtenues avec l'utilisation de ce porte-greffe (14,4\% de moins par rapport au contrôle). D'autre part, plus de P a été noté dans les fruits de 'Coyote' greffé sur 'Charlot' (17,2 \% de plus par rapport au contrôle). Pour cette combinaison, la plus haute teneur en $\mathrm{K}$ a également été notée dans les fruits $\left(226,7 \mathrm{mg}^{100} \mathrm{~g}^{-1}\right.$ poids frais). Conclusion. D'un point de vue nutritionnel, il est important d'évaluer et de sélectionner les meilleures combinaisons porte-greffe-greffon, qui a été dans notre essai 'Charlot' - 'Coyote' où les fruits ont montré les plus fortes valeurs de ${ }^{\circ}$ Brix, et teneurs en $\mathrm{K}$, $\mathrm{P}$ et protéines.
\end{abstract}

Mots clés : poivron / piment doux / Capsicum annuum / qualité du fruit / composition minérale / combinaison porte-greffe-greffon

\section{Introduction}

Pepper (Capsicum annuum L.) fruit is an important source of nutrients in the human diet. Fresh pepper has a high content of vitamin $\mathrm{C}$ and represent a good source of phenolics and provitamin A carotenoids $[1,2]$. Pepper also provides significant quantities of certain minerals, such as $\mathrm{P}, \mathrm{K}, \mathrm{Ca}$, and $\mathrm{Fe}[3]$.

Because of the phasing-out of methyl bromide, interest in the grafting of horticultural plants in order to provide resistance to soilborne pathogens has increased in recent years and several studies have focused on the establishment of grafting methodology and on yield production under biotic stress in both commonly grafted plants like watermelon (Citrullus lanatus (Thunb.) Matsum. \& Nakai) or tomato (Solanum lycopersicum L.) and others, like eggplant (Solanum melongena L.), pepper or melon (Cucumis melo L.) [4-7]. In pepper, several attempts to develop useful rootstocks or test commercially available ones have been reported [8-16]; however scarce evaluation of the fruit quality performance was carried out $[11,14$ 16] despite the fact that changes in pepper scion characteristics as a consequence of grafting had been reported early [17]. Effects of grafting on horticultural fruit quality have been reviewed in $[4,18,19]$. From the reported work, we can conclude that fruit quality characteristics and composition can be modified or not as a consequence of grafting and when modifications are produced positive or detrimental effects can be obtained $[19,20]$. In addition to rootstock-scion interactions, cultural practices and environmental conditions may greatly influence fruit quality. For example in [21] two cultivars of tomato ('Fanny' and 'Goldmar') were grafted onto the rootstock 'AR-9704' and grown under distinct saline conditions $(0,30$ or $60 \mathrm{mM})$. A specific root-scion interaction for vitamin $\mathrm{C}$ was found with cv. Fanny; fruit from grafted plants had a higher vitamin $C$ concentration, mainly under saline irrigation. Also for this root-scion combination the glucose and fructose concentrations were higher at $0 \mathrm{mM} \mathrm{NaCl}$. Modification of the minerals content or translocation of compounds as a consequence of grafting has been reported also. For instance, grafting tomato onto the 'He-Man' rootstock lowered the leaf and root iron and copper concentrations but enhanced potassium [22]. In addition to the modification of standard fruit components, other compounds synthesized by the rootstocks may be found in the scion; for example, the accumulation of high amounts of nicotine in tomato plants grafted onto Nicotiana tabacum L. [23]. In the specific case of pepper, several changes related with the capsaicin content [17], vigor [11,16], fruit shape index [15], or carotenoids, total phenolics and vitamin $C$ contents $[14,16]$ have been reported.

In previous work [12] we tested, as putative rootstocks of sweet pepper, the pepper hybrids 'Foc' and 'Charlo' - which share the parent Serrano Criollo de Morelos (SCM334) [10], a common source of resistance to Phytophthora capsici Leonian $[24,25]$. Both hybrids showed resistance to $P$. capsici and good agronomic performance [12]. In addition, high resistance to the nematode Meloidogyne incognita Kofoid and White (neither galls nor reproduction in infested soils) was proven in 'SCM334' and 'Charlot' [26] as well as in 'Foc' (data not shown). The resistance to soil-borne pathogens and the increasing interest in the use of grafting for the management of soil-borne pathogens have led us to evaluate both rootstocks, focusing on the putative modifications of the nutritional quality (dry matter, total soluble sugars, mineral composition, proteins, phenolics, and ascorbic acid) that may occur as a consequence of grafting. As scions, we have used 'Coyote' and 'Almuden', representative sweet pepper cultivars grown in southeastern Europe.

\section{Materials and methods}

\subsection{Plant material and growth conditions}

The commercial $F_{1}$ pepper hybrids 'Almuden' (A) and 'Coyote' (C) (Syngenta Seeds) were used as scions. 'Almuden' is a Lamuyo-type pepper (elongated rectangular shape) and 'Coyote' a California-type (more square). 'Charlot' $(\mathrm{CH})$ and 'Foc' $(\mathrm{F})$ were chosen as rootstocks. Fruits from non-grafted (A, C), self-grafted (C-C; A-A), and grafted plants (CH-C; F$\mathrm{C}, \mathrm{CH}-\mathrm{A}, \mathrm{F}-\mathrm{A})$ were used to study the possible changes in nutritional content. Grafted plants were obtained using the cleft method [2].

For each treatment (A, A-A, CH-A, F-A, C, C-C, CHC, F-C), 15-20 plants were transplanted in March 2010 to 
pots $(27 \times 32 \mathrm{~cm})$ filled with non-fertilized coconut fiber substrate and were distributed randomly in a greenhouse of the UPV (Valencia, Spain). The plants were placed $0.4 \mathrm{~m}$ apart in rows separated by gaps of $1.7 \mathrm{~m}$. They were watered using a drip irrigation system. Pressure-compensated emitters that delivered $4 \mathrm{Lh}^{-1}$ were used for the drip irrigation. The final concentrations of the main anions and cations in the irrigation solution (ions in the irrigation water plus those supplied as fertilizers) were: $11.7 \mathrm{mM} \mathrm{NO}_{3}^{-}, 1.5 \mathrm{mM} \mathrm{H}_{2} \mathrm{PO}_{4}^{-}, 3.6 \mathrm{mM}$ $\mathrm{SO}_{4}^{2-}, 0.5 \mathrm{mM} \mathrm{HCO}_{3}^{-}, 2.3 \mathrm{mM} \mathrm{Cl}^{-}, 1.0 \mathrm{mM} \mathrm{NH}_{4}^{+}, 5.5 \mathrm{mM}$ $\mathrm{K}^{+}, 5.0 \mathrm{mM} \mathrm{Ca}^{2+}, 2.3 \mathrm{mM} \mathrm{Mg}^{2+}$ and $1.9 \mathrm{mM} \mathrm{Na}^{+}$. Micronutrients were supplied by adding the following salts to the irrigation water: $50 \mu \mathrm{M} \mathrm{H}_{3} \mathrm{BO}_{3}, 10 \mu \mathrm{M}$ FeEDTA, $4.5 \mu \mathrm{M} \mathrm{MnCl}_{2}$, $3.8 \mu \mathrm{M} \mathrm{ZnSO}{ }_{4}, 0.3 \mu \mathrm{M} \mathrm{CuSO}_{4}$ and $0.1 \mu \mathrm{M}\left(\mathrm{NH}_{4}\right)_{6} \mathrm{Mo}_{7} \mathrm{O}_{24}$. Excess water was applied in order to avoid salt buildup in the pots and to maintain a homogenous concentration of the nutrients and salts in the coconut fiber substrate. This hydroponic system was used in order to avoid the experimental error associated with heterogeneity of the soil and of the availability of water resulting from cultivation in soil [27].

One fully-mature (red) fruit per plant (one replication) was collected 110 days after transplanting. The total number of fruits for each treatment was $n=13$ for 'Almuden' and A-A, $n=14$ for 'Coyote', and $n=20$ for the rest of the treatments (CH-A, F-A, C-C, CH-C, and F-C). The maturity stage was determined with the CIEL*** coordinates, using a Minolta CR-300 (Osaka, Japan) colorimeter.

\subsection{Preparation of samples}

Immediately after harvest, the fruits were weighed and brought to the laboratory where they were washed. Each fruit was cut longitudinally into two halves. For each plant, one half of the fruit was squeezed using a domestic juice extractor and the juice was used to determine the vitamin $\mathrm{C}$ and phenolic contents. Immediately after the juice extraction, $5 \mathrm{~mL}$ of the homogenate corresponding to each plant were poured into $10 \mathrm{~mL}$ of an extraction solution, consisting of acetone $(70 \% \mathrm{v} / \mathrm{v})$ and glacial acetic acid $(0.5 \% \mathrm{v} / \mathrm{v})$, and left for $1 \mathrm{~h}$ at approximately $24{ }^{\circ} \mathrm{C}$ for phenolic extraction before being frozen at $-20{ }^{\circ} \mathrm{C}$ until analysis. The rest of the homogenate was used for the measurement of soluble solids. The other half of the fruit was weighed after drying to constant weight at $105{ }^{\circ} \mathrm{C}$, powdered with a mechanical grinder and used for the measurement of dry matter and protein and mineral concentrations.

\subsection{Analytical methods}

Ascorbic acid was determined by titration with chloramine $\mathrm{T}$, using an automatic titration system (Titrino $702 \mathrm{SM}$, in MEAS mode) (Metrohm, Herisau, Switzerland) equipped with a selective electrode. Total soluble solids were determined by an $\mathrm{N}-20 \mathrm{E}$ refractometer (ATAGO, Japan) at $20^{\circ} \mathrm{C}$. Dry matter was determined as $[100 \times($ dry weight/fresh weight $)]$

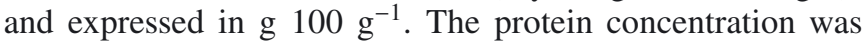
estimated from the nitrogen concentration obtained through the Kjeldahl method using a Kjeltec 2100 Distillation Unit (Foss Tecator, Högamäs, Sweden), as nitrogen $\times 6.25$. Phenolic compounds were determined by the Folin-Ciocalteu procedure [28]. An aliquot of $1.3 \mathrm{~mL}$ of the supernatant of the extracted phenolic sample was mixed with $1 \mathrm{~mL}$ of diluted $(10 \%$ v/v) Folin-Ciocalteu reagent (Sigma-Aldrich Chemie, Steinheim, Germany) and allowed to stand at approximately $24{ }^{\circ} \mathrm{C}$ for $5 \mathrm{~min}$. After that, $1 \mathrm{~mL}$ sodium carbonate solution $\left(60 \mathrm{~g} \mathrm{~L}^{-1}\right)$ was added to the mixture. After $90 \mathrm{~min}$ at $24^{\circ} \mathrm{C}$, the absorbance was measured at $760 \mathrm{~nm}$ in a Jenway 6305 UV-VIS spectrophotometer (Jenway, Essex, UK). Chlorogenic acid (Sigma-Aldrich Chemie) was used as standard. The phenolic acid concentration was expressed as chlorogenic acid equivalents as mg $100 \mathrm{~g}^{-1}$ fresh fruit weight (FW).

For the mineral analyses, $2 \mathrm{~g}$ of the dried samples were calcinated in a furnace at $450{ }^{\circ} \mathrm{C}$ for $2 \mathrm{~h}$ (after which they had a light color) and then weighed. The ashes were then dissolved in $2 \mathrm{~mL} \mathrm{HCl}$. The mixture was heated until the first vapors appeared, and distilled water $(2-3 \mathrm{~mL})$ was added immediately. Subsequently, the mixture was filtered and the extract was brought to $100 \mathrm{~mL}$ with distilled water. Phosphorus was analyzed by the molybdovanadate method, using a Jenway 6305 UV-VIS spectrophotometer, potassium and sodium were analyzed by flame photometry, using a Jenway PFP7 flame photometer (Jenway, Essex, UK), and the other minerals $(\mathrm{Ca}, \mathrm{Mg}, \mathrm{Fe}, \mathrm{Cu}$, and $\mathrm{Zn}$ ) were analyzed by atomic absorption spectrophotometry, using a Thermo Elemental (SOLAAR AA Spectrometers, Cambridge, UK) spectrometer [29].

\subsection{Statistical analyses}

The data were analyzed by analysis of variance (ANOVA), using the Statgraphics software package. Differences among means were tested using the Bonferroni test, for a significance level of $P<0.05$.

\section{Results and discussion}

It has been reported in different horticultural crops, including pepper, that grafting could affect plant yield and modify the fruit traits of scions $[4,18,19]$. The changes in scion characteristics have been mainly related to a higher capacity fo water and nutrient uptake by the vigorous roots of rootstocks $[5,20,22]$ and/or translocation of endogenous hormones or other metabolites between the rootstock and scion [30,31]. In order to determine the putative effects of the promising rootstocks 'Charlot' and 'Foc' on pepper fruit quality parameters, the representative sweet peppers 'Almuden' and 'Coyote' were used as scions and fruit from grafted, self-grafted, and ungrafted plants, collected at similar maturity stages, were processed for analysis.

\subsection{Yield and yield component}

In pepper, the influence of the rootstock or rootstock-scion combination on yield has been reported $[8,15,16]$. For instance, in non-infested soil, [8] found, with respect to the nongrafted control, a lower yield when grafting the cultivar 
Table I. Main effects of grafting on weight, fruit number and yield of pepper (Capsicum annuum L.).

\begin{tabular}{cccc}
\hline Treatment & $\begin{array}{c}\text { Mean fruit } \\
\text { weight }(\mathrm{g})\end{array}$ & $\begin{array}{c}\text { Fruit number } \\
\text { per plant }\end{array}$ & $\begin{array}{c}\text { Yield } \\
\left(\mathrm{kg} \mathrm{plant}^{-1}\right)\end{array}$ \\
\hline Grafting (GR) & & & \\
Ungrafted & $227.55 \mathrm{~b}$ & $8.85 \mathrm{a}$ & $2.00 \mathrm{a}$ \\
Self-grafted & $212.13 \mathrm{ab}$ & $9.95 \mathrm{a}$ & $2.12 \mathrm{a}$ \\
'Charlot'-grafted & $189.98 \mathrm{a}$ & $10.52 \mathrm{a}$ & $2.01 \mathrm{a}$ \\
'Foc'-grafted & $188.97 \mathrm{a}$ & $10.90 \mathrm{a}$ & $1.96 \mathrm{a}$ \\
\hline Scion genotype (SG) & & & \\
'Coyote' & $181.96 \mathrm{a}$ & $10.45 \mathrm{a}$ & $1.89 \mathrm{a}$ \\
'Almuden' & $227.35 \mathrm{~b}$ & $9.65 \mathrm{a}$ & $2.16 \mathrm{a}$ \\
\hline Significance & & & \\
GR & $P<0.001$ & $\mathrm{NS}$ & $\mathrm{NS}$ \\
SC & $P<0.001$ & $\mathrm{NS}$ & $\mathrm{NS}$ \\
GR $\times$ SG & $P<0.05$ & $\mathrm{NS}$ & $\mathrm{NS}$ \\
\hline
\end{tabular}

NS: non-significant, or significant at $P<0.05$. Means followed by different letters are significantly different at $P<0.05$ (Bonferroni test). Data were obtained from 15 plants of A, A-A and $\mathrm{C}$ and 20 plants of the rest of combinations (C-C, CH-C, F-C, CH-A, F-A).

'Parker' onto the C. annuum rootstock 'AR-96023', whereas a similar yield was obtained when 'Celica' was used as scion. In this work, intraspecific variability was also observed regarding the influence on yield when using different accessions of C. frutescens as rootstocks [8]. In our assay, the yield was similar for all treatments. However, although no significant differences were obtained for yield, the tendency was for a higher number of fruits with lower mean fruit weight in grafted plants with respect to ungrafted plants (table I). The number of fruits per plant ranged from 8.8 in ungrafted plants to 10.9 in 'Foc'-grafted plants, with respective mean fruit weights (g) of 227.5 and 189.0 (table I). In [16] the greater yield obtained in some pepper rootstock-scion combinations was associated with higher fruit number rather than fruit weight. Differences for weight between varieties were expected because 'Almuden' is a Lamuyo-type pepper which fruits have larger size than those of 'Coyote' which belongs to California-type peppers.

\subsection{Fruit quality parameters}

Among the fruit quality parameters evaluated in this work, dry matter, protein, soluble solids $\left({ }^{\circ}\right.$ Brix $)$, and phenolics were significantly influenced by grafting, whereas the ascorbic acid concentration was mainly dependent on the scion genotype (table II). Grafting-scion genotype $(\mathrm{GR} \times \mathrm{S})$ interactions were also obtained for dry matter, ${ }^{\circ}$ Brix, phenolics, and, at a lower significance level, for ascorbic acid (table $I I)$.

Higher protein and dry matter $(P>0.001)$ levels were measured in fruit from grafted plants, particularly plants grafted onto 'Charlot' or 'Foc' rootstock. Thus, fruits from 'Almuden' and 'Coyote' plants grafted onto 'Charlot' had, respectively, $17.8 \%$ and $16 \%$ more protein than fruits from ungrafted plants, whereas increases of $20.8 \%$ and $13.4 \%$ in the protein concentration were obtained for 'Almuden' and 'Coyote' fruits, respectively, in 'Foc'-grafted plants. The dry matter content was, on average, $11.8 \%$ higher in fruit from plants grafted onto 'Charlot' and 'Foc', in comparison with fruit from non-grafted controls. Both increments could be associated with higher uptake and transport of nutrients [20, 32, 33], as indicated in this work by the higher levels of macronutrients in the fruit from grafted plants (table III).

Higher ${ }^{\circ}$ Brix values and concentrations of phenolic compounds were noted in the fruit of 'Coyote' with respect to those of 'Almuden': the respective averages were 8.4 and $7.1{ }^{\circ}$ Brix and 1.23 and $1.12 \mathrm{mg} \mathrm{g}^{-1} \mathrm{FW}$ for phenolics ( $\mathrm{ta}$ ble $I I)$. The ${ }^{\circ}$ Brix of these varieties was within the range commonly reported for sweet peppers $[11,34]$. The levels of phenolics in the fruit from our scion genotypes were in the range of those reported by [35] in red peppers. The 'Foc' rootstock produced an average reduction of $16.6 \%$ in the ${ }^{\circ}$ Brix of 'Almuden' and 'Coyote' fruits. Similarly, a lower concentration of phenols $(14.4 \%$ less) was found in fruits from plants grafted onto this rootstock (table II). In pepper, changes in the SS content due to grafting have been reported [4]. Regarding phenolics no changes as a consequence of grafting were found in Chávez-Mendoza et al. [14]. In López-Marín et al. [16] lower values were found in the fruit of cv. Herminio grafted onto 'Creonte' in comparison to the rest of combinations It is difficult to compare previous studies because different rootstock-scion combinations and quality traits were analyzed.

The ascorbic acid concentration is highly dependent on genotype [36]. Our work shows a higher concentration of vitamin C in fruits from 'Almuden' than in those of 'Coyote' (on average, 177.42 vs. $150.90 \mathrm{mg} 100^{-1} \mathrm{~g}^{-1} \mathrm{FW}$ ). 'Almuden' fruits from self-grafted plants had the lowest vitamin $\mathrm{C}$ concentration, whereas for 'Coyote' the vitamin $\mathrm{C}$ concentration was similar in all treatments. Grafting onto 'Charlot' or 'Foc' did not modify the vitamin $\mathrm{C}$ level. In [16] differences for vitamin C in fruit of 'Herminio' were obtained depending on the rootstock and culture conditions: under "shaded" conditions, higher vitamin $\mathrm{C}$ levels were found in fruit from plants grafted onto 'Atlante' whereas the contrary occurred in non-shaded conditions, where higher content was noted in fruit from plants grafted onto 'Creonte' or 'Terrano'. An increase of Vitamin C in pepper grafted plants was also reported in [14]. 
Table II. Dry matter, soluble solids (SS), protein, phenolics, and ascorbic acid of 'Coyote' and 'Almuden' pepper (Capsicum annuum L.) fruits produced from non-grafted (A, C) and self-grafted (A-A; C-C) plants and plants grafted onto 'Charlot' (CH-A, CH-C) or 'Foc' (F-A, F-C) rootstocks. A. Main effects of grafting and scion genotype on the measured traits. B. Effect of rootstock-scion combinations on the measured quality parameters.

\begin{tabular}{|c|c|c|c|c|c|}
\hline & $\begin{array}{l}\text { Dry matter } \\
(\%)\end{array}$ & $\begin{array}{c}\text { Protein } \\
\left(\mathrm{g} 100 \mathrm{~g}^{-1}\right)\end{array}$ & $\begin{array}{c}\text { SS } \\
\left({ }^{\circ} \text { Brix }\right)\end{array}$ & 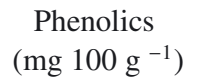 & 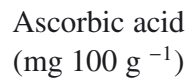 \\
\hline \multicolumn{6}{|l|}{ A. Grafting-scion } \\
\hline \multicolumn{6}{|l|}{ Grafting (GR) } \\
\hline Ungrafted & $7.98 \mathrm{a}$ & $0.67 \mathrm{a}$ & $8.26 \mathrm{~b}$ & $120.08 \mathrm{a}$ & $169.28 \mathrm{~b}$ \\
\hline Self-grafted & $8.39 \mathrm{a}$ & $0.74 \mathrm{ab}$ & $8.00 \mathrm{~b}$ & $116.45 \mathrm{a}$ & $157.39 \mathrm{a}$ \\
\hline 'Charlot'-grafted & $8.91 \mathrm{~b}$ & $0.78 \mathrm{~b}$ & $7.90 \mathrm{~b}$ & $126.81 \mathrm{~b}$ & $167.95 \mathrm{~b}$ \\
\hline 'Foc'-grafted & $8.94 \mathrm{~b}$ & $0.79 b$ & $6.89 \mathrm{a}$ & $102.78 \mathrm{a}$ & $162.03 \mathrm{a}$ \\
\hline \multicolumn{6}{|l|}{ Scion genoype (SG) } \\
\hline 'Coyote' & $8.51 \mathrm{a}$ & $0.76 \mathrm{a}$ & $8.40 \mathrm{~b}$ & $122.94 \mathrm{a}$ & $150.90 \mathrm{a}$ \\
\hline 'Almuden' & $8.60 \mathrm{a}$ & $0.73 \mathrm{a}$ & $7.07 \mathrm{a}$ & $111.73 \mathrm{~b}$ & $177.42 \mathrm{~b}$ \\
\hline \multicolumn{6}{|l|}{ Significance } \\
\hline Grafting (GR) & $P<0.001$ & $P<0.001$ & $P<0.001$ & $P<0.001$ & $P<0.01$ \\
\hline Scion genotype (SG) & NS & NS & $P<0.001$ & $P<0.01$ & $P<0.001$ \\
\hline $\mathrm{GR} \times \mathrm{S}$ & $P<0.001$ & NS & $P<0.001$ & $P<0.001$ & $P<0.05$ \\
\hline \multicolumn{6}{|l|}{ B. Rootstock-scion } \\
\hline A & $8.14 \mathrm{a}$ & 0.652 & $7.86 \mathrm{~b}$ & $120.91 \mathrm{a}$ & $188.89 \mathrm{c}$ \\
\hline A-A & $8.70 \mathrm{bcd}$ & $0.725 \mathrm{ab}$ & $7.95 \mathrm{~b}$ & 95.71 & $161.92 \mathrm{~b}$ \\
\hline $\mathrm{CH}-\mathrm{A}$ & $8.72 \mathrm{bcd}$ & $0.768 \mathrm{bc}$ & $6.33 \mathrm{a}$ & $121.70 \mathrm{a}$ & $181.07 \mathrm{c}$ \\
\hline F-A & $8.54 \mathrm{abc}$ & 0.788 & $6.14 \mathrm{a}$ & $105.97 \mathrm{a}$ & $177.78 \mathrm{c}$ \\
\hline $\mathrm{C}$ & $7.84 \mathrm{a}$ & $0.685 \mathrm{ab}$ & $8.65 \mathrm{c}$ & $119.24 \mathrm{ab}$ & $149.67 \mathrm{a}$ \\
\hline $\mathrm{C}-\mathrm{C}$ & $8.07 \mathrm{a}$ & $0.766 \mathrm{bc}$ & $8.05 \mathrm{~b}$ & $138.30 \mathrm{~b}$ & $152.86 \mathrm{a}$ \\
\hline $\mathrm{CH}-\mathrm{C}$ & $9.20 \mathrm{c}$ & 0.795 & $9.49 \mathrm{~d}$ & $131.92 \mathrm{~b}$ & $154.82 \mathrm{a}$ \\
\hline $\mathrm{F}-\mathrm{C}$ & $9.24 \mathrm{~d}$ & 0.777 & $7.63 \mathrm{~b}$ & 99.58 & $146.27 \mathrm{a}$ \\
\hline $\begin{array}{c}\text { Significance } \\
(P \text {-value })\end{array}$ & 0.000 & 0.000 & 0.000 & 0.000 & 0.000 \\
\hline
\end{tabular}

Means followed by different letters are significantly different at $P<0.05$ (Bonferroni test). One mature fruit per plant (at similar mature stage) wascollected at 110 after transplanting ( $n=13$ for A and A-A; $n=14$ for C and $n=20$ for C-C, CH-C, F-C, CH-; F-A). One measurement per fruit was performed. Each value data is the mean of measurements performed for each rootstock-scion combination.

The concentrations of the minerals in this study (table III) are within the normal range for fruits of this species [3, 37]. Among the minerals measured, potassium was the most abundant, followed by $\mathrm{P}, \mathrm{Na}, \mathrm{Mg}$, and $\mathrm{Ca}$. Among the micronutrients, $\mathrm{Zn}$ had the highest concentration, followed by $\mathrm{Cu}$ and $\mathrm{Fe}$ (table III). Concerning the effects of grafting, no significant differences between treatments were observed for $\mathrm{Cu}, \mathrm{Zn}$, or $\mathrm{Ca}$, which showed average values of $0.1,0.2$, and $9.1 \mathrm{mg}$ $100 \mathrm{~g}^{-1} \mathrm{FW}$, respectively. The concentrations of $\mathrm{Fe}, \mathrm{Mg}$, and Na were significantly $(P<0.000)$ affected by the scion genotype (table III). The lowest Fe concentration was recorded in 'Coyote' (0.02 mg $100 \mathrm{~g}^{-1} \mathrm{FW}$ ) and the lowest values of $\mathrm{Mg}$ and $\mathrm{Na}$ were found in the 'Almuden' fruits (13.0 and $18.1 \mathrm{mg}$ $100 \mathrm{~g}^{-1} \mathrm{FW}$ for $\mathrm{Mg}$ and $\mathrm{Na}$, respectively). Grafting significantly $(P<0.001)$ affected the $\mathrm{K}$ and $\mathrm{P}$ concentrations $(t a-$ ble III), which were also influenced by genotype in the case of $\mathrm{P}$ (38.9 vs. $34 \mathrm{mg} 100 \mathrm{~g}^{-1} \mathrm{FW}$ in Coyote' and 'Almuden', respectively). Both these macronutrients had higher concentrations in all the grafting treatments, but mainly in fruits of plants grafted onto 'Charlot' or 'Foc' rootstock (on average, $10 \%$ higher). The highest increase was produced in fruits from the combination 'Charlot'-'Coyote', which had $16 \%$ higher $\mathrm{K}$ and $17 \%$ higher $\mathrm{P}$ with respect to fruits obtained from non-grafted plants, followed by those of 'Foc'- 'Coyote', with $14.5 \%$ higher $\mathrm{K}$ and $7 \%$ higher $\mathrm{P}$. The higher $\mathrm{P}$ and $\mathrm{K}$ concentrations agree with the higher dry matter and protein levels found in fruit from grafted plants. Many studies have revealed that some graft combinations were significantly more efficient with regard to the uptake and transport to the shoot of nutrients such as $\mathrm{K}, \mathrm{N}, \mathrm{P}, \mathrm{Mg}, \mathrm{Ca}, \mathrm{Fe}$, or other micronutrients, in comparison with non-grafted plants [38]. In some reports, the increment in $\mathrm{K}$ as a consequence of grafting was related to increased concentrations of lycopene [20,39] and carotenoids [40]. We found an increment of $\mathrm{K}$ in the fruit from 'Coyote' plants grafted onto both tested rootstocks. From a nutritional point of view this result is interesting because fruit and vegetables usually contribute $35 \%$ of the total $\mathrm{K}$ to the dietary intake of humans [41].

\section{Conclusion}

The composition of pepper fruit has been found to vary depending on the genotype, rootstock, or rootstock-scion combination - which underlines the importance of incorporating these factors, and their interactions, into the experimental 
Table III. Mineral content ( $\mathrm{Fe}, \mathrm{Cu}, \mathrm{Mn}, \mathrm{Zn}, \mathrm{Ca}, \mathrm{Mg}, \mathrm{K}, \mathrm{P}$, and $\mathrm{Na}$ ) of 'Coyote' and 'Almuden' pepper fruit produced from non-grafted (A, C) and self-grafted (A-A; C-C) plants and plants grafted onto 'Charlot' (CH-A, CH-C) or 'Foc' (F-A, F-C) rootstocks. A. Main effects of grafting and scion genotype on mineral content. B. Effect of rootstock-scion combinations on the mineral content. Data in $\mathrm{mg} 100 \mathrm{~g}^{-1}$ fresh weight.

\begin{tabular}{|c|c|c|c|c|c|c|c|c|}
\hline & $P$ & $\mathrm{~K}$ & $\mathrm{Ca}$ & $\mathrm{Mg}$ & $\mathrm{Na}$ & $\mathrm{Fe}$ & $\mathrm{Cu}$ & $\mathrm{Zn}$ \\
\hline \multicolumn{9}{|l|}{ A. Grafting/Scion } \\
\hline \multicolumn{9}{|l|}{ Grafting (GR) } \\
\hline Non-grafted & $32.93 \mathrm{a}$ & $202.78 \mathrm{a}$ & $9.10 \mathrm{a}$ & $14.76 \mathrm{ab}$ & $22.51 \mathrm{a}$ & $0.025 \mathrm{ab}$ & $0.070 \mathrm{a}$ & $0.180 \mathrm{a}$ \\
\hline Self-grafted & $35.77 \mathrm{ab}$ & $208.06 \mathrm{ab}$ & $9.19 \mathrm{a}$ & $17.79 \mathrm{~b}$ & $21.62 \mathrm{a}$ & $0.027 b$ & $0.073 \mathrm{a}$ & $0.238 \mathrm{a}$ \\
\hline 'Charlot' -grafted & $37.37 \mathrm{~b}$ & $222.87 b$ & $9.38 \mathrm{a}$ & $14.03 \mathrm{a}$ & $20.70 \mathrm{a}$ & $0.021 \mathrm{a}$ & $0.063 \mathrm{a}$ & $0.243 \mathrm{a}$ \\
\hline 'Foc'-grafted & $35.75 \mathrm{ab}$ & $221.62 b$ & $9.71 \mathrm{a}$ & $16.52 \mathrm{ab}$ & $20.75 a$ & $0.025 \mathrm{ab}$ & $0.067 \mathrm{a}$ & $0.182 \mathrm{a}$ \\
\hline \multicolumn{9}{|l|}{ Scion genotype (SG) } \\
\hline 'Coyote' & $36.82 b$ & 212.71a & $9.66 \mathrm{a}$ & $18.51 b$ & $24.66 b$ & $0.021 \mathrm{a}$ & $0.067 \mathrm{a}$ & $0.207 \mathrm{a}$ \\
\hline 'Almuden' & $34.12 \mathrm{a}$ & $214.68 \mathrm{a}$ & $9.03 \mathrm{a}$ & $13.03 \mathrm{a}$ & $18.12 \mathrm{a}$ & $0.028 \mathrm{~b}$ & $0.069 \mathrm{a}$ & $0.214 \mathrm{a}$ \\
\hline \multicolumn{9}{|l|}{ Significance } \\
\hline Grafting (GR) & $P<0.001$ & $P<0.001$ & NS & $P<0.01$ & NS & $P<0.01$ & NS & NS \\
\hline Scion genotype (SG) & $P<0.001$ & NS & NS & $P<0.001$ & $P<0.001$ & $P<0.001$ & NS & NS \\
\hline $\mathrm{GR} \times \mathrm{S}$ & NS & $P<0.05$ & NS & $P<0.05$ & NS & NS & NS & NS \\
\hline \multicolumn{9}{|l|}{ B. Root-scion } \\
\hline A & $32.10 \mathrm{a}$ & $210.05 \mathrm{abc}$ & $8.62 \mathrm{a}$ & $12.93 \mathrm{abc}$ & $18.44 \mathrm{a}$ & $0.029 \mathrm{~b}$ & $0.073 \mathrm{a}$ & $0.179 \mathrm{a}$ \\
\hline A-A & $33.91 \mathrm{ab}$ & $210.13 \mathrm{abc}$ & $9.75 \mathrm{a}$ & $16.46 \mathrm{bcd}$ & $19.39 \mathrm{a}$ & $0.029 \mathrm{~b}$ & $0.080 \mathrm{a}$ & $0.250 \mathrm{a}$ \\
\hline $\mathrm{CH}-\mathrm{A}$ & $35.15 \mathrm{ab}$ & $219.14 \mathrm{bc}$ & $8.56 \mathrm{a}$ & $10.60 \mathrm{a}$ & $17.25 \mathrm{a}$ & $0.025 \mathrm{ab}$ & $0.063 \mathrm{a}$ & $0.262 \mathrm{a}$ \\
\hline F-A & $35.31 \mathrm{ab}$ & $219.42 \mathrm{bc}$ & $9.30 \mathrm{a}$ & $12.16 \mathrm{ab}$ & $17.66 \mathrm{a}$ & $0.028 \mathrm{~b}$ & $0.064 \mathrm{a}$ & $0.167 \mathrm{a}$ \\
\hline $\mathrm{C}$ & $33.77 \mathrm{ab}$ & $195.54 \mathrm{a}$ & $9.34 \mathrm{a}$ & $16.49 \mathrm{bcd}$ & $26.41 \mathrm{~b}$ & $0.021 \mathrm{ab}$ & $0.069 \mathrm{a}$ & $0.183 \mathrm{a}$ \\
\hline $\mathrm{C}-\mathrm{C}$ & $37.73 \mathrm{bc}$ & $204.62 \mathrm{ab}$ & $8.72 \mathrm{a}$ & $19.12 \mathrm{~d}$ & $24.71 \mathrm{~b}$ & $0.023 \mathrm{ab}$ & $0.067 \mathrm{a}$ & $0.233 \mathrm{a}$ \\
\hline $\mathrm{CH}-\mathrm{C}$ & $39.59 \mathrm{c}$ & $226.70 \mathrm{c}$ & $10.18 \mathrm{a}$ & $17.46 \mathrm{~cd}$ & $24.19 \mathrm{~b}$ & $0.018 \mathrm{a}$ & $0.063 \mathrm{a}$ & $0.219 \mathrm{a}$ \\
\hline $\mathrm{F}-\mathrm{C}$ & $36.20 \mathrm{bc}$ & $223.98 \mathrm{bc}$ & $10.29 \mathrm{a}$ & $20.86 \mathrm{~d}$ & $23.93 \mathrm{~b}$ & $0.022 \mathrm{ab}$ & $0.067 \mathrm{a}$ & $0.192 \mathrm{a}$ \\
\hline $\begin{array}{c}\text { Significance } \\
(P \text {-value })\end{array}$ & 0.000 & 0.001 & 0.095 & 0.000 & 0.000 & 0.000 & 0.098 & 0.161 \\
\hline
\end{tabular}

Means followed by different letters are significantly different at $P<0.05$ (Bonferroni test). One mature fruit per plant (at similar mature stage) was collected at 110 after transplanting ( $n=13$ for A and A-A; $n=14$ for C and $n=20$ for C-C, CH-C, F-C, CH-; F-A). One measurement per fruit was performed. Each value data is the mean of measurements performed for each rootstock-scion combination.

design. From a nutritional point of view, the best rootstockscion combination of those evaluated was 'Charlot'-'Coyote', for which the fruit showed higher soluble solids ( ${ }^{\circ}$ Brix), K, P, and protein concentrations.

Acknowledgements. This work was funded by the Fundación Agroalimed (supported by the Valencian regional government - the Comunidad Valenciana). We thank Dr. David Walker for the revision of the written English in the manuscript.

\section{References}

[1] Vanderslice J.T., Higgs D.J., Hayes J.M.,Block G., Ascorbic acid and dehydroascorbic acid content of food-as-eaten, J. Food Composition Anal. 3 (1990) 105-118.

[2] Zhang D., Hamauzu Y. Phenolic compounds, ascorbic acid, carotenoids and antioxidant constituents of green, red and yellow bell peppers, J. Food Agric. Environ. 24 (2003) 345-351.

[3] Ensminger A.H., Foods and Nutrition Encyclopedia, $2^{\text {nd }}$ ed, Boca Ratón, USA: CRC Press, 1994.

[4] Blestos F.A., Olympios C.M., Rootstock and grafting tomatoes, peppers and eggplants for soil-borne disease resistance, improved yield and quality, Eur. J. Plant Sci. Biotech. 2 (2008) $62-73$.
[5] Lee J.M., Kubota C., Tsao S.J., Bie Z., Hoyos-Echevarria P., Morra L., Oda M.,Current status of vegetable grafting: Diffusion, grafting techniques, automation, Sci. Hortic. 127 (2010) 93-105.

[6] Louws F.J., Rivard C.L., Kubota C., Grafting fruiting vegetables to manage soilborne pathogens, foliar pathogens, arthropods and weeds, Sci. Hortic. 127 (2010) 127-146.

[7] Gisbert C., Prohens J., Raigón M.D., Stommel J., Nuez F., Eggplant relatives as sources of variation for developing new rootstocks: effects of grafting on yield and fruit apparent quality and composition, Sci. Hortic. 128 (2011) 14-22.

[8] Oka Y., Offenbach R., Pivonia S. Pepper rootstock graft compatibility and response to Meloidogyne javanica and M. incognita, J. Nematol 36 (2004) 137-141.

[9] Morra L., Bilotto, M., Evaluation of new rootstocks for resistance to soil-borne pathogens and productive behaviour of pepper (Capsicum annuum L.), Hort. Sci. Biotech. 81 (2006) 518-524.

[10] Gisbert C., Sánchez-Torres P., Nuez F. Development of hybrids for pepper grafting: evaluation of Phytophtora capsici resistance, in: Prohens Badenes Eds., Modern variety breeding for present and future needs (pp. 378-383), Valencia, España: UPV Editorial, 2008. 
[11] Colla G., Rouphael Y., Cardarelli M., Temperini O., Rea E., Salerno A., Pierandrei F. Influence of grafting on yield and fruit quality of pepper (Capsicum annuum L.) grown under greenhouse conditions, Acta Hortic. 782 (2008) 359-36.

[12] Gisbert C, Sánchez-Torres P., Raigón M.D., Nuez F., Phytophthora capsici resistance evaluation in pepper hybrids: Agronomic performance and fruit quality of pepper grafted plants, J. Food Agric. Environ. 8 (2010) 116-121.

[13] Saporta R., Gisbert C., 2013. Growth and Fruit Production in pepper grafted onto C. annuum, C. baccatum and C. pubescens genotypes Lanteri and Rotino, in: (Eds), Breakthroughs in the genetics and breeding of Capsicum and eggplant (pp. 641-644), Torino, Italy: Prontostampa srl, 2013.

[14] Chávez-Mendoza C., Sánchez E., Carvajal-Millán E., MunõzMárquez E., Guevara-Aguillar A., Characterization of the nutraceutical quality and antioxidant activity in bell pepper in response to grafting, Molecules 18 (2013) 15689-15703.

[15] Leal-Fernández C., Godoy-Hernández H., Núñez-Colín C.A., Anaya-López J.A., Villalobos-Reyes S., Castellanos J.Z., Morphological response and fruit yield of sweet pepper (Capsicum annuum L.) grafted onto different commercial rootstocks, Biol. Agric. Hortic. 29 (2013) 1-11.

[16] López-Marín J., González A., Pérez-Alfocea F., Egea-Gilabert C., Fernández, J.A. Grafting is an efficient alternative to shading screens to alleviate thermal stress in greenhouse-grown sweet pepper, Sci. Hortic. 149 (2013) 39-46.

[17] Yagishita N., Hirata Y., Okochi K., Mimura K., Mizukami H., Ohashi H., Characterization of graft-induced change in capsaicin content of Capsicum annuum L., Euphytica 34 (1985) 297-301.

[18] Davies A. R., Perkins-Veazie P., Hassell R., Levi A., King S.R., Zhang X.P., Grafting effects on vegetable quality, HortSci. 43 (2008) 1670-1672.

[19] Rouphael Y., Schwarz D., Krumbein A., Colla G., Impact of grafting on product quality of fruit vegetables, Sci. Hortic. 127 (2010) 172-179.

[20] Lee J.M. Cultivation of grafted vegetables I, current status, grafting methods and benefits, HortSci. 29 (1994) 235-239.

[21] Fernández-García, N., Martínez, V., Cerdaì, A., Carvajal, M: Fruit quality of grafted tomato plants grown under saline conditions, J. Hort. Sci. Biotechnol. 79 (2004) 995-1001.

[22] Savvas D., Papastavrou D., Ntatsi G., Ropokis A., Olympios C., Interactive effects of grafting and manganese supply on growth, yield, and nutrient uptake by tomato, HortSci. 44 (2009) 1978-1982.

[23] Yasinok A. E., Sahin F.I., Eyidogan F., Kuru M., Heberal M., Grafting tomato plant on tobacco plant and its effects on tomato plant yield and nicotine content, J. Sci. Food. Agric. 89 (2009) 1122-1128.

[24] Ortega R.G., Palazon-Espanol C., Cuartero-Zueco J., Genetics of resistance to Phytophthora capsici in the pepper line 'SCM334', Plant Breed. 107 (1991) 50-55.

[25] Thabuis A., Lefebvre V., Bernard G., Daubeze A.M., Phaly T., Pochard E., Palloix A. Phenotypic and molecular evaluation of a recurrent selection program for a polygenic resistance to Phytophthora capsici in pepper, Theor. Appl. Genet. 109 (2004) 342-351.
[26] Gisbert C., Trujillo-Moya C., Sánchez-Torres P., Sifres A. Sánchez-Castro E., Nuez F., Resistance of pepper germplasm to Meloidogyne incognita, Ann. Appl. Biol. 162 (2013) 110-118.

[27] Jensen M.H., Collins W.L., Hydroponic vegetable production, Hortic. Rev. 7, (1985) 48-558.

[28] Singleton V.L., Rossi J.A., Colorimetry of total phenolics with phosphomolybdic phosphotungstic acid reagents, Am. J. Enol. Vitic. 16 (1965) 144-158.

[29] MAPA. Métodos Oficiales de Análisis, vol. II., Madrid, Spain: Ministerio de Agricultura, Pesca y Alimentación, 1994.

[30] Lee J.M., Oda M. Grafting of herbaceous vegetable and ornamental crops, Hortic. Rev 28 (2003) 61-87.

[31] Albacete A., Martínez-Andújar C., Ghanem M. E., Acosta M., Sánchez-Bravo J., Asins M.J., Cuartero J., Lutts S., Dodd I. C., Pérez-Alfocea F. Rootstock-mediated changes in xylemionic and hormonal status are correlated with delayed leaf senescence, and increased leaf area and crop productivity in salinized tomato, Plant Cell Environ. 32 (2009) 928-938.

[32] Leonardi C., Giuffrida F., Variation of plant growh and macronutrient uptake in grafted tomatoes and eggplants on three different rootstocks, Eur. J. Hortic. Sci. 71 (2006) 97-101.

[33] Pulgar G., Villora G., Moreno D.A., Romero L. Improving the mineral nutrition in grafted watermelon plants: nitrogen metabolism, Biol. Plant. 43 (2000) 607-609.

[34] Renquist A.R., La Grange M.J., Searle B.P., Reid J.B., Towards a control theory for acidity of vegetable crops, Acta Hortic. 694 (2005) 463-469.

[35] Zhuang Y. Chen L. Sun L., Cao J., Bioactive characteristics and antioxidant activities of nine peppers, J. Funct. Foods (2012) $331-338$.

[36] Guil-Guerrero J.L., Martínez-Guirado C., Rebolloso-Fuentes M.M., Carrique-Pérez A., (2006). Nutrient composition and antioxidant activity of 10 pepper (Capsicum annuum) varieties, Eur. Food Res. Technol. 224 (2006) 1-9.

[37] Belitz H.D., Grosh W., Química de los alimentos. Zaragoza, Spain: Acribia (1997).

[38] Savvas D., Colla G., Rouphael Y., Schwarz D. Amelioration of heavy metal and nutrient stress in fruit vegetables by grafting, Sci. Hortic 127 (2010) 156-161.

[39] Fanasca S., Colla G., Rouphael Y., Saccardo F., Maiani G., Venneria E., Azzini E.,Evolution of nutritional value of two tomato genotypes grown in soilless culture as affected by macrocation proportions, HortSci. 41 (2006) 1584-1588.

[40] Davies A.R., Perkins-Veazie P., Sakata I., López-Galarza S., Maroro J.V., Lee S.G., Huh Y.C., Sun Z., Miguel A., King S.R., Cohe R., Lee J.M., Cucurbit grafting, Crit. Rev. Plant Sci. 27 (2008) 50-74.

[41] Levander O.A., Fruit and vegetable contributions to dietary mineral intake in human health and disease, HortSci. 25 (1990) 1486-1488. 
Resumen - Influencia del injerto (combinaciones patrón-copa) en la composición nutricional de pimiento. Introducción. El interés por el injerto en pies resistentes a patógenos presentes en el suelo ha aumentado desde la retirada del bromuro de metilo, un eficiente desinfectante. En este estudio hemos evaluado la posible influencia del injerto (combinaciones patrón-copa) en la calidad nutricional del pimiento. Este tipo de evaluaciones pueden ser de interés y no se llevan a cabo comúnmente. Materiales y métodos. Como copas hemos utilizado dos variedades de pimiento dulce representativas 'Almuden' y 'Coyote' y como patrones 'Foc' y 'Charlot', ambos resistentes a Phytophthora capsici y Meloidogyne incognita. Se ha determinado el peso seco y el contenido en sólidos solubles, proteínas, fenoles, vitamina C, P, K, $\mathrm{Ca}, \mathrm{Mg}, \mathrm{Na}, \mathrm{Fe}, \mathrm{Cu}$, y $\mathrm{Zn}$ en frutos colectados en plantas no injertadas, en plantas autoinjertadas y en plantas injertadas en los patrones en evaluación. Resultados y discusión. Se han encontrado diferencias en la composición de los frutos dependiendo del genotipo, el patrón utilizado o la combinación patrón-copa. Los principales efectos observados han sido: la obtención de valores superiores para ${ }^{\circ}$ Brix, fenoles, $\mathrm{P}, \mathrm{Mg}$, y $\mathrm{Na}$ en frutos de 'Coyote' y un mayor contenido en vitamina $\mathrm{C}$ y Fe en 'Almuden'. En frutos de plantas injertadas, el peso seco, el contenido en proteína y en $\mathrm{K}$ fue superior al obtenido en plantas no injertadas, siendo superior en aquellos procedentes de plantas injertadas en 'Charlot' y 'Foc' (incrementos del 11,8\%, 17,6\%, y 9,6\%, respectivamente; promedios de las cuatro combinaciones). Los frutos de 'Almuden' y 'Coyote' de plantas injertadas en 'Foc' mostraron valores de ${ }^{\circ}$ Brix inferiores (un grado menos que el control aprox.). También fue menor el contenido en fenoles en frutos de plantas injertadas en este patrón (14,4\% menos que el control). Por otra parte, la concentración de P fue mayor en los frutos de 'Coyote' colectados en plantas injertadas en 'Charlot' (17,2\% superior al control). Los frutos de esta combinación también mostraron la mayor concentración de K (226,70 mg $100 \mathrm{~g}^{-1}$ peso fresco). Conclusión. Desde un punto de vista nutricional, es importante realizar este tipo de evaluaciones para seleccionar aquellas que sean superiores -en nuestro estudio- la combinación 'Charlot'- 'Coyote', cuyos frutos mostraron los mayores valores de ${ }^{\circ}$ Brix y el mayor contenido en $\mathrm{K}$, P, y proteína.

Cite this article as: Paloma Sánchez-Torres, María Dolores Raigón, Najet Gammoudi, Carmina Gisbert. Effects of grafting combinations on the nutritional composition of pepper fruit. Fruits 71(4) (2016) 249-256. 